\title{
The Jackass Penguin (Spheniscus demersus) as a pelagic predator
}

\author{
R. P. Wilson \\ Percy FitzPatrick Institute of African Ornithology, University of Cape Town, Rondebosch, 7700, South Africa
}

\begin{abstract}
Swimming and diving capabilities of Jackass Penguin Spheniscus demersus were examined. Mean maximum speed over a $10 \mathrm{~m}$ course in a rock pool was $12.4 \mathrm{~km} \mathrm{~h}^{-1}$ for breeders, 9.5 $\mathrm{km} \mathrm{h}^{-1}$ for juveniles and $4.6 \mathrm{~km} \mathrm{~h}^{-1}$ for fledglings. Theoretically fledglings could not swim fast enough to catch adult Cape Anchovies Engraulis capensis, the normal prey of adults. Fledglings probably feed on fish larvae. Moulting penguins swam at speeds comparable to fledglings and did not feed. When travelling to the foraging area, breeding penguins swam at $4.8 \mathrm{~km} \mathrm{~h}^{-1}$. Maximum theoretical foraging range is $24.2 \mathrm{~km}$, but actual range was $<20 \mathrm{~km}$. Mean duration of dive was $22.3 \mathrm{~s}$ inside Saldanha Bay and 146 s outside the bay. During long dives outside Saldanha Bay, penguins were probably foraging. At midday, when most Jackass Penguins are at sea, largest numbers were seen outside the bay in 30 to $40 \mathrm{~m}$ depth. Penguins fitted with depth gauges dived routinely to $30 \mathrm{~m}$, but spent most time in the upper water layers. Maximum recorded depth was $130 \mathrm{~m}$. There was a positive correlation between distance swum and amount of food ingested. This suggests that the anchovy on which they feed formed small schools which were encountered frequently.
\end{abstract}

\section{INTRODUCTION}

Penguins are flightless marine birds which rely on their swimming abilities to travel to their foraging grounds, and to locate and capture prey. Swimming is much slower than flying so flightlessness would seem disadvantageous. Penguins cannot theoretically cover as large a foraging area as aerial seabirds and are not, therefore, adapted to feed on temporally or spatially unpredictable prey where a large area must be covered in order to encounter the prey. Penguins are, nevertheless, one of the most successful bird families in the Antarctic and sub-Antarctic, comprising about $80 \%$ of the bird biomass on many islands (Croxall 1984).

Penguins feed on pelagic prey (Zusi 1975) which have several adaptations for avoiding predation, i.e. aggregative behaviour (Hamner et al. 1983) which reduces the probability of predator-prey encounter (Cushing \& Harding-Jones 1968), schooling (Pitcher \& Partridge 1979, Partridge 1980) where aggregations are highly organised so that the prey can react to minimize predation after they have been discovered (Partridge 1980), and diel vertical migration (Boden \& Kampa 1967).

This paper presents data on the behaviour of the Jackass Penguin Spheniscus demersus to illustrate how the species is adapted to feed on its principal prey, the Cape Anchovy Engraulis capensis (Rand 1960, Furness \& Cooper 1982, Wilson 1985).

\section{MATERIALS AND METHODS}

Field work was conducted at Saldanha Bay $\left(33^{\circ} 03^{\prime} \mathrm{S}\right.$, $17^{\circ} 58^{\prime} \mathrm{E}$ ), southwestern Cape Province, South Africa from May 1980 to July 1981 and in May 1984 particularly at the penguin breeding colony at Marcus Island, Saldanha Bay.

The maximum speeds of Jackass Penguins of different ages: juveniles (first year birds), feathered chicks about to depart to sea, breeding adults, and moulting adults, were determined by timing, with a stop watch, birds swimming over a $10 \mathrm{~m}$ distance in a rock pool (dimensions approximately $15 \times 2 \times 1 \mathrm{~m}$ ). The birds were given a $1 \mathrm{~m}$ stretch in which to accelerate before being timed. They were alarmed when released, apparently traveling as fast as possible and generally swimming directly from 1 end to the other. Any bird that did not swim the course directly was omitted from calculations. The state of moult was scored as percentage of the old feathers lost. Premoult birds were recognised by their pale plumage and greater mass and post- 
moult birds by their dark plumage, short tail, and lack of skin around the eye (Cooper 1978).

Jackass Penguins normally travel by swimming underwater, alternating with periods on the surface. I measured both the surface-paddling speed and the underwater speed of penguins at sea by noting the angular difference between surface 'stops' and the distance between myself and the birds at succesive stops (using a simple device for measuring angular displacement and a rangefinder). The use of vectors coupled with the time taken between surface stops allowed calculation of speed. It was assumed that the penguins travelled in a straight line while underwater. The rangefinder could not be used reliably if the birds were further away than about $300 \mathrm{~m}$. The maximum error in measurements, as determined by calculating unknown distances between randomly placed poles on a beach and then checking with a measuring tape, was less than $10 \%$.

At midday on 28 May 1984, 15 Jackass Penguins guarding chicks were weighed to the nearest $50 \mathrm{~g}$ and fitted with autoradiographic speed/distance meters (Wilson \& Bain 1984a) which were attached to the feathers with hose-clips (Lishman \& Croxall 1983). The speed/distance meter consisted of a spring-mounted bead of radioactive phosphorus ${ }^{32} \mathrm{P}$ and a waterproofed film. The bead position was determined by the speed that the penguin swam. This position was recorded autoradiographically on the film. The time spent travelling at various speeds was ascertained by reading the optical density of the trace on the film (Wilson \& Bain 1984a). These birds left the island to forage on 29 May. The chicks were weighed at $1500 \mathrm{~h}$ on 29 May and subsequently the nests were checked every hour for returning adults which returned after approximately $11 \mathrm{~h}$ at sea. When the penguins with devices returned, they and their chicks were reweighed and the devices removed. The increase in mass of the chicks plus the increase in mass of the adults was assumed to represent a relative measure of the mass of food that the penguins had ingested that day.

Penguin density at sea in specific areas was noted by running transects in a $10 \mathrm{~m}$ motor-boat at a constant speed (between $25 \mathrm{~km} \mathrm{~h}^{-1}$ and $30 \mathrm{~km} \mathrm{~h}^{-1}$ ), and counting the numbers of penguins visible per kilometre. The penguins were spotted from the middle of the boat where the observer was about $4 \mathrm{~m}$ above the water. A semi-circle $\left(90^{\circ}\right.$ on either side of the boat) was surveyed and any penguins within about $70 \mathrm{~m}$ were counted. All transects were conducted on days with good visibility when single penguins on the surface could be seen easily up to the $70 \mathrm{~m}$ limit. Transects were conducted in Langebaan Lagoon, and inside and outside Saldanha Bay (Fig. 1). Fourteen transects were conducted from May 1980 to July 1981 inclusive between $1115 \mathrm{~h}$ and $1330 \mathrm{~h}$ when most Jackass Penguins are at sea (Wilson 1985). The route of each transect is shown in Fig. 1.

Dive durations for travelling and foraging Jackass Penguins were determined with a stop watch by observing the birds from islands (Jutten, Malagas and Marcus) and from stationary boats.

The depth to which Jackass Penguins dive and the time spent at each depth was examined by using autoradiographic depth gauges described by Wilson \& Bain (1984b). The devices worked on the same principle as the speed/distance meters (see above) with a radioisotope $\left({ }^{32} \mathrm{P}\right)$ recording time spent at each depth autoradiographically on film. The device did not record individual dives, but recorded the cumulative total time spent at each depth by the bird per foraging trip. Between 15 December 1980 and 30 May 1981, depth gauges were attached to 15 breeding adults before they left the island at dawn to forage, and recovered when they returned in the evening.

In order to investigate the schooling behaviour of the penguins' prey, the stomachs of 61 Cape Anchovies caught by purse-seine fishing boats were examined and graded as empty, full or intermediate. Thirty-one of the fish were taken from a shoal estimated at $1500 \mathrm{t}$ approximately $5 \mathrm{~km}$ south of Saldanha Bay on 23 March 1981, and 30 fish were taken from 9 smaller shoals, each estimated between 20 and $50 \mathrm{t}$, caught approximately $90 \mathrm{~km}$ north of Saldanha Bay on 14 April 1981. The stomachs of 122 anchovies taken by 17 Jackass Penguins between 15 March 1981 and 22 June 1981, were graded in the same way.

\section{RESULTS}

The speeds of travel of different age categories of the Jackass Penguin in different modes varied considerably (Table 1). A Kruskal-Wallis 1-way analysis of variance (Siegel 1956) showed that the maximum speed of non-moulting adults was significantly higher than the maximum speed of juveniles which in turn was significantly higher than the maximum speed of fledglings $(P<0.001)$. Penguins swimming over short distances underwater do not seem capable of speeds in excess of about $20 \mathrm{~km} \mathrm{~h}^{-1}$. Most values lie between 10 and $20 \mathrm{~km} \mathrm{~h}^{-1}$ (e.g. Meinertzhagen 1955, Clark \& Bemis 1979) though the lower speeds may not be representative of the birds' maxima.

The comparatively high maximum speed of premoult penguins (approx $13.5 \mathrm{~km} \mathrm{~h}^{-1}$ ) dropped to only $4 \mathrm{~km} \mathrm{~h}^{-1}$ when moult started (Fig. 2). The maximum speed of birds remained very low until about $70 \%$ of the old feathers had been shed, rising to about $10 \mathrm{~km}$ 
Fig. 1. Map of Saldanha Bay illustrating densities of Jackass penguins Spheniscus demersus at sea along transects made from boats between $1115 \mathrm{~h}$ and $1330 \mathrm{~h}$, May 1980 through July 1981 Number of runs per transect: A-C: $5 ; \mathrm{F}-\mathrm{G}: 2$; B-F: 2; D-E: $1 ;$ G-H: $1 ;$ A-J: 1; J-B: 1. Stars indicate islands where penguins breed

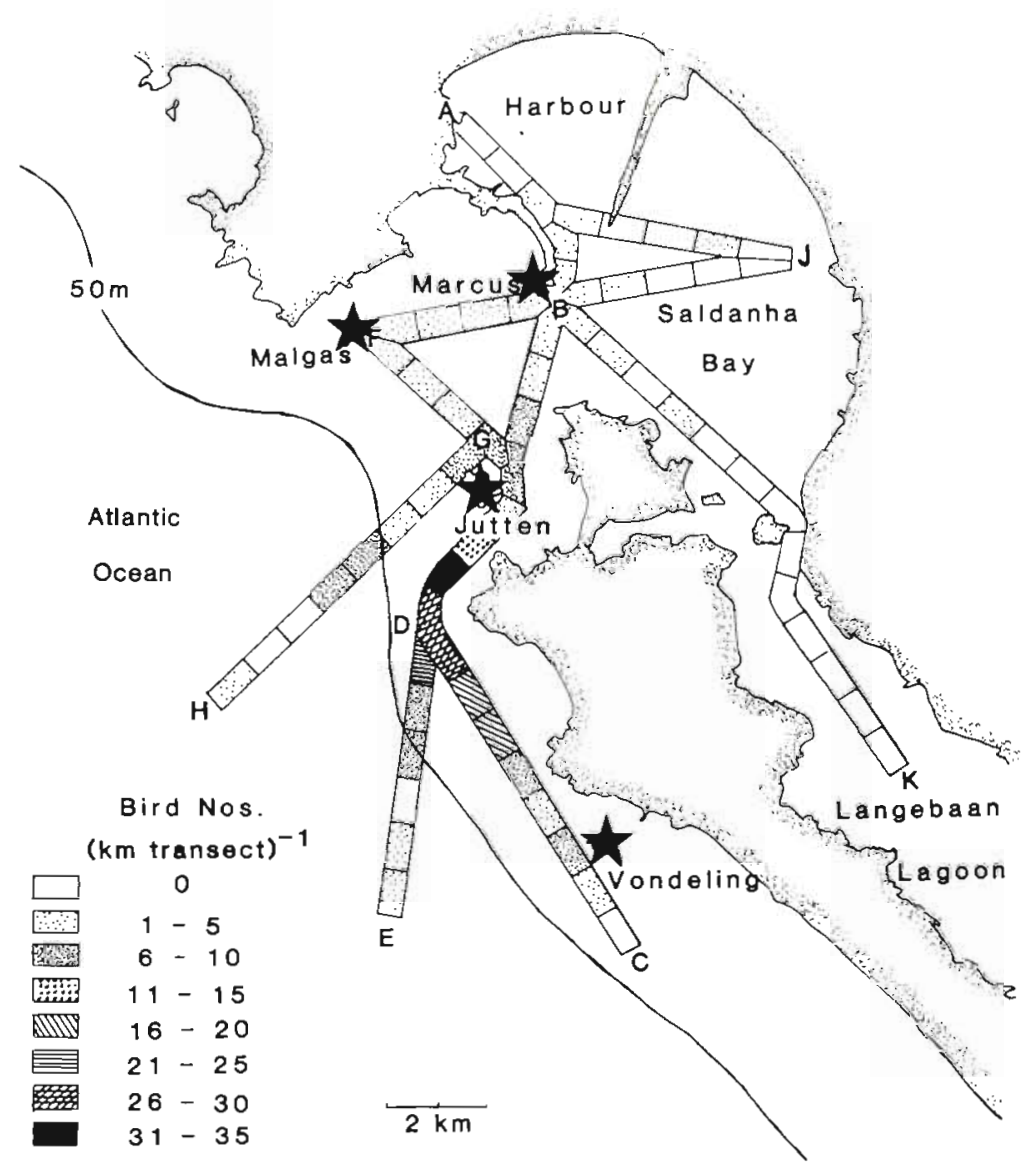

Table 1. Penguin swimming speeds. Activities: (1) underwater sprint; (2) underwater; (3) 'normal' underwater travel; (4) 'normal' surface travel; (5) normal travel, underwater/surface; (6)return to home island after release elsewhere. Method of calculation: (A) stopwatch; (B) goniometer and stopwatch; (C) speed meter; (D) timed

\begin{tabular}{|c|c|c|c|c|c|c|c|}
\hline \multirow[t]{2}{*}{ Species } & \multirow[t]{2}{*}{ Distance } & \multicolumn{4}{|c|}{ Speed $\left(\mathrm{km} \mathrm{h}^{-1}\right)$} & \multirow{2}{*}{\multicolumn{2}{|c|}{$\begin{array}{l}\text { Activity, Method of } \\
\text { calculation, Source }\end{array}$}} \\
\hline & & Mean & $\mathrm{SD}$ & $n$ & $\max$ & & \\
\hline Jackass Penguin adult & $10 \mathrm{~m}$ & 12.4 & 2.4 & 50 & 18.8 & (1) (A) & This study \\
\hline Jackass Penguin juvenile & $10 \mathrm{~m}$ & 9.5 & 1.8 & 17 & 12.8 & (1) (A) & This study \\
\hline Jackass Penguin fledgling & $10 \mathrm{~m}$ & 4.6 & 0.8 & 14 & 6.2 & (1) (A) & This study \\
\hline Jackass Penguin & Short & - & & - & 11.6 & (2) (A) & Clark \& Bemis 1979 \\
\hline Jackass Penguin groups & $<200 \mathrm{~m}$ & 1.5 & 0.6 & 22 & 3.1 & (4) (B) & This study \\
\hline Jackass Penguin groups & $<200 \mathrm{~m}$ & 4.7 & 1.6 & 18 & 6.5 & (5) (B) & This study \\
\hline Jackass Penguin & Not given & $4-7$ & & - & - & (5) & Frost et al. 1976 \\
\hline Jackass Penguin & Not given & $7-9$ & & - & - & (5) & Davis 1955 \\
\hline Jackass Penguin & $200 \mathrm{~m}$ & 4.9 & & - & - & (5) & Siegfried et al. 1975 \\
\hline Jackass Penguin groups & $<200 \mathrm{~m}$ & 6.7 & 1.7 & 20 & 10.6 & (3) (B) & This study \\
\hline Jackass Penguin & $<40 \mathrm{~km}$ & 6.6 & 0.8 & 15 & - & (3) (C) & Wilson \& Bain 1984a \\
\hline Jackass Penguin & $900 \mathrm{~km}$ & - & & - & 2.1 & (6) (D) & S. Afr. J. Sci. 1979 \\
\hline \multicolumn{8}{|l|}{ Emperor Penguin } \\
\hline Aptenodytes forsteri & $27 \mathrm{~m}$ & 9.6 & & - & - & (2) (A) & Kooyman et al. 1971 \\
\hline \multicolumn{8}{|l|}{ King Penguin } \\
\hline Aptenodytes patagonicus & Short & - & & - & 12.1 & (2) $(A\}$ & Clark \& Bemis 1979 \\
\hline \multicolumn{8}{|l|}{ Adelie Penguin } \\
\hline Pygoscelis adelie & $21 \mathrm{~m}$ & - & & - & 13.3 & (2) (A) & Meinertzhagen 1955 \\
\hline \multicolumn{8}{|l|}{ Little Blue Penguin } \\
\hline Eudyptula minor & - & 5.6 & & - & - & (3) & Barton 1979 \\
\hline Little Blue Penguin & Short & - & & - & 6.2 & (2) (A) & Clark \& Bemis 1979 \\
\hline
\end{tabular}




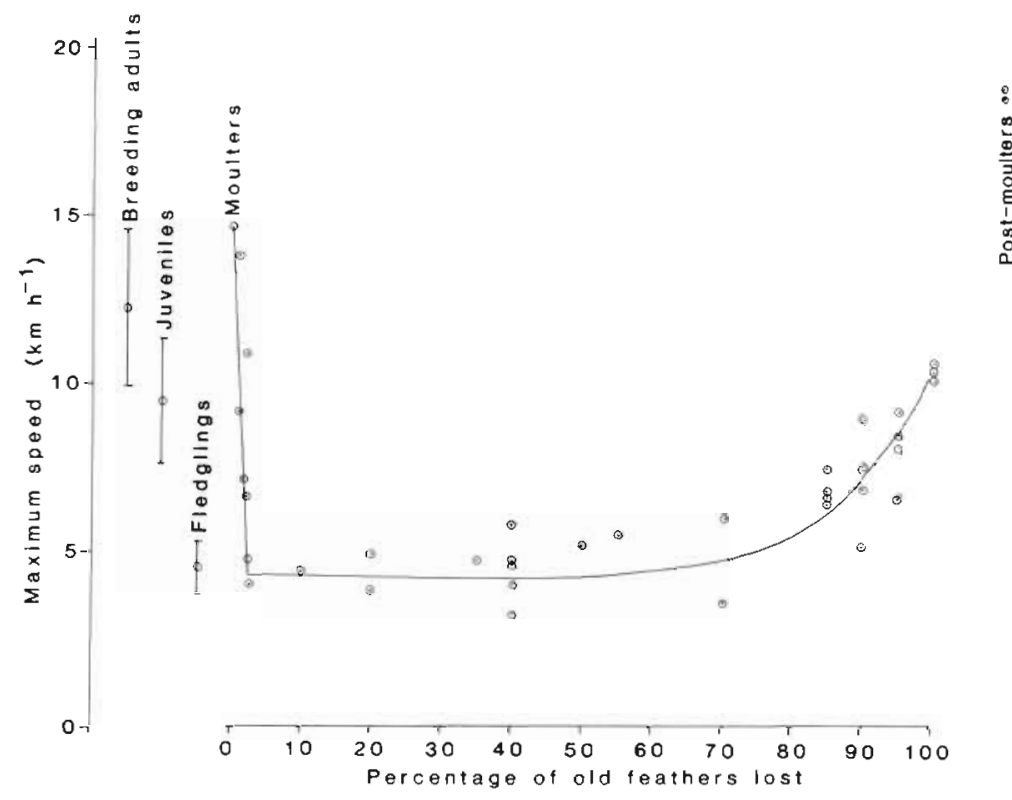

Fig. 2. Spheniscus demersus. Maximum speeds of 5 categories of Jackass Penguins, timed over a $10 \mathrm{~m}$ course in a rock pool. Vertical bars are standard deviations

$\mathrm{h}^{-1}$ upon completion of moult (Fig. 2). By way of comparison, the maximum speeds of prey species of Jackass Penguins are shown in Table 2.

When travelling to and from their feeding grounds, Jackass Penguins normally travelled underwater, alternating with periods on the surface. The underwater speed of Jackass Penguins in the bay was $6.7 \mathrm{~km}$ $\mathrm{h}^{-1}(\mathrm{SD} 1.7, n=20)$, similar to the value of $6.6 \mathrm{~km} \mathrm{~h}^{-1}$ recorded by Wilson \& Bain (1984a) using an autoradiographic speed distance meter on free-swimming penguins (Table 1). These underwater speeds must be combined with the surface travelling speed to obtain the average penguin travelling speed. The ratio of time spent underwater to time spent on the surface for a travelling Jackass Penguin was 22.3 s (Table 3) to 17.8 $\mathrm{s}$ (Siegfried et al. 1975). Jackass Penguins travelled at $1.5 \mathrm{~km} \mathrm{~h}^{-1}$ when swimming on the surface (Table 1), therefore the actual travelling speed, which is composed of surface and underwater components, was $(22.3 \times 6.7)+(17.8 \times 1.5) / 40.1=4.4 \mathrm{~km} \mathrm{~h}^{-1}$. Direct measurements showed the actual travelling speed was $4.7 \mathrm{~km} \mathrm{~h}^{-1}$ (SD 1.6, $n=18$ ) (Table 1). Jackass Penguins generally leave their breeding islands around dawn and return in the late afternoon (Frost et al. 1976). If they travel at $4.4 \mathrm{~km} \mathrm{~h}^{-1}$, allowing for the return journey, the maximum range of a Jackass Penguin during the approximately $11 \mathrm{~h}$ period is $24.2 \mathrm{~km}$.

The 15 penguins fitted with distance meters travelled a mean distance of $40.2 \mathrm{~km}$ (SD 22.0) which means that most birds did not venture further than $20.1 \mathrm{~km}$ from their breeding island. The regression of mass of fish caught per bird versus distance travelled has a correlation coefficient ( $r$ ) of 0.89 (Fig. 3).

During the transects, no penguins were seen in Langebaan Lagoon or in Saldanha harbour, and very few were seen in the bay. Most Jackass Penguins were found outside the bay in water approximately 30 to $40 \mathrm{~m}$ deep. Few were seen in water deeper than $50 \mathrm{~m}$ (Fig. 1).

Inside the bay, the mean duration of dives for Jackass Penguins was 22.3 s (SD 11.6, $n=34$ ). Outside the bay the mean duration was $146 \mathrm{~s}$ (SD 59.5, $n=16$ ). When disturbed by a boat, the birds typically dived for less than $15 \mathrm{~s}$ (Table 3 ).

The mean time spent at various depths for 15 foraging penguins, as determined by the autoradiographic

Table 2. Maximum speeds of Jackass Penguin prey

\begin{tabular}{lll|}
\hline Species & Max speed $\left(\mathrm{km} \mathrm{h}^{-1}\right)$ & Source \\
\hline $10 \mathrm{~cm}$ 'fish' & ca 9 & Wardle 1975 \\
Clupoeids (10 cm long) & ca 2.5 & Webb 1975 \\
Jack Mackerel Trachurus symmetricus & 7.6 & Hunter \& Zweifel 1971 \\
Round Herring Etrumeus teres & ca 11 & Local fishermen (speed relative to fishing vessel) \\
Anchovy adult Engraulis capensis & ca 8 & Local fishermen (speed relative to fishing vessel) \\
Anchovy larvae Engraulis mordax & 1.1 & Hunter 1972 \\
& &
\end{tabular}


Table 3. Penguin dive times

\begin{tabular}{|c|c|c|c|c|c|c|}
\hline \multirow[b]{2}{*}{ Species } & \multicolumn{5}{|c|}{ Dive times (s) } & \multirow[b]{2}{*}{ Source } \\
\hline & Dives & Mean & $\mathrm{SD}$ & Range & $n$ & \\
\hline Jackāss Penguin & In bay & 22.3 & 11.6 & $7-48$ & 34 & This study \\
\hline Jackass Penguin & Disturbed by boat & $<15$ & & - & - & This study \\
\hline Jackass Penguin & Outside bay & 146.9 & 59.5 & $42-247$ & 16 & This study \\
\hline Jackass Penguin & Fishing? & ca 20 & & $<45$ & - & Siegfried et al. 1975 \\
\hline \multicolumn{7}{|l|}{ Humboldt Penguin } \\
\hline Spheniscus humboldti & Fishing & 75 & 45 & - & 18 & Duffy 1983 \\
\hline \multicolumn{7}{|l|}{ Galapagos Penguin } \\
\hline S. mendiculus & & $<30$ & & $<79$ & - & Boersma 1976 \\
\hline \multicolumn{7}{|l|}{ Macaroni Penguin } \\
\hline Eudyptes chrysolophus & Force dived & - & & $<300$ & - & Scholander 1940 \\
\hline \multicolumn{7}{|l|}{ Gentoo Penguin } \\
\hline Pygoscelis papua & Fishing? & - & & $<120$ & 8 & Kooyman 1975 \\
\hline Gentoo Penguin & Fishing & 128 & & $<203$ & - & Trivelpiece et al. unpubl. \\
\hline Gentoo Penguin & Force dived & - & & $<420$ & - & Scholander 1940 \\
\hline \multicolumn{7}{|l|}{ Chinstrap Penguin } \\
\hline P. antarctica & Fishing & 91 & & $<139$ & - & Trivelpiece et al. unpubl. \\
\hline \multicolumn{7}{|l|}{ Adelie Penguin } \\
\hline$P$, adelie & & $<45$ & & - & - & Wilson \\
\hline Adelie Penguin & & 114 & & - & - & Smith unpubl. \\
\hline Adelie Penguin & Forced dived & - & & $<360$ & - & Donald 1895 \\
\hline \multicolumn{7}{|l|}{ Emperor Penguin } \\
\hline Aptenodytes forsteri & Exploring under ice & - & & $<1080$ & - & Kooyman et al. 1971 \\
\hline Emperor Penguin & Fishing? & - & & $<540$ & - & Kooyman 1975 \\
\hline
\end{tabular}

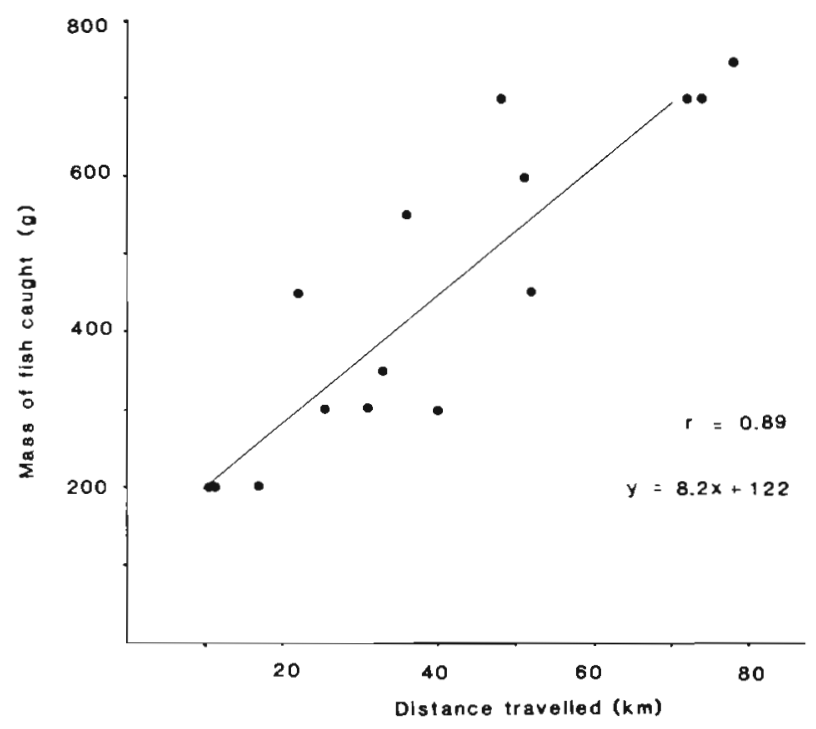

Fig. 3. Spheniscus demersus. Relation between mass of anchovy ingested and total distance travelled per foraging trip, for Jackass Penguins breeding at Marcus Island during May 1984

depth gauge (Wilson \& Bain 1984b) is shown in Fig. 4 . The maximum depth recorded was $130 \mathrm{~m}$, but most birds did not dive deeper than $30 \mathrm{~m}$. In general more time was spent at shallow depths. The mean time per $11 \mathrm{~h}$ foraging trip spent deeper than $3 \mathrm{~m}$, where the birds were assumed to be foraging rather than travelling, was $78 \mathrm{~min}$.

Anchovies from a $1500 \mathrm{t}$ school had significantly less full stomachs than anchovies from 20 to $50 \mathrm{t}$ schools which had less full stomachs than anchovies caught by penguins (Table 4) $(2 \times 2$ contingency tests, $p<0.05$; Siegel 1956).

\section{DISCUSSION}

\section{Maximum speed and prey availability}

The ability to swim fast enhances the penguin's chances of capturing prey. The principal prey of the Jackass Penguin in the Saldanha Bay region is the Cape Anchovy, but Round Herring Etrumeus teres and Jack Mackerel Trachurus trachurus are also taken (Wilson 1985). Since the Jackass Penguin feeds in open

Table 4. Number of anchovy with full, partially full, and empty stomachs from a $1500 \mathrm{t}$ school, 20 to $50 \mathrm{t}$ schools and from penguin stomach samples

\begin{tabular}{|c|c|c|c|}
\hline & $\begin{array}{l}1500 \mathrm{t} \\
\text { school }\end{array}$ & $\begin{array}{l}20-50 \mathrm{t} \\
\text { schools }\end{array}$ & $\begin{array}{c}\text { Penguin } \\
\text { diet }\end{array}$ \\
\hline Full stomachs & $1(3 \%)$ & $4(13 \%)$ & $25(21 \%)$ \\
\hline Partially full stomachs & $8(26 \%)$ & $18(60 \%)$ & $86(70 \%)$ \\
\hline Empty stomachs & $22(71 \%)$ & $8(27 \%)$ & $11(9 \%)$ \\
\hline
\end{tabular}




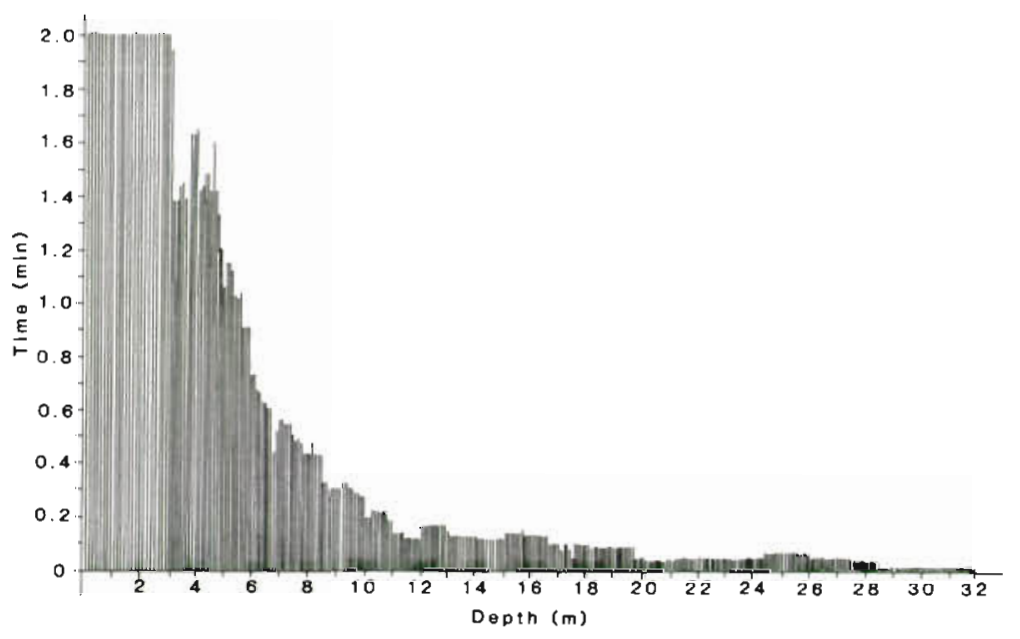

Fig. 4. Spheniscus demersus. Mean time spent at different depths for 15 foraging Jackass Penguins that spent $1 \mathrm{~d}$ at sea

water (Rand 1960), 'stalking' the prey does not seem likely (Hobson 1979). To capture any of these fish the bird must swim faster than its prey, at least over short distances. The data show that while breeding adults can outpace all their prey species, juvenile penguins may experience difficulty securing Round Herring. Fledglings would be unable to catch any of the prey species, suggesting that fledglings have different foods from adults. Most of the slow-moving macrozooplankton in the region (Thiriot 1978) are too small or live too deep (e.g. Talbot 1974) to constitute Jackass Penguin prey. Fish larvae (from about $12 \mathrm{~mm}$ long) do occur in Jackass Penguin stomachs (Wilson unpubl.). The maximum speed of fish larvae is considerably less than the maximum speed of fledgling Jackass Penguins and so young Jackass Penguins may rely on larval and juvenile fish. Rand (1960) also concluded that 'immature' Jackass Penguins (no distinction was made between juvenile and fledgling) preyed upon slowmoving species.

The smooth-feathered surface of a non-moulting penguin is crucial for fast, efficient swimming (Nachtigall \& Bilo 1980). The loss of speed during moult can be attributed to the loose uplifted feather layer covering the body. Although moulting Jackass Penguins may not venture into the water for thermoregulatory reasons (Erasmus et al. 1981), they may also suspend feeding (Cooper 1978) because they are too slow to capture their prey. Fasting and regenerating new feathers substantially reduces the size of the pectoralis and supracoracoideus muscles (pers. obs.), the principal swimming muscles (Schreiweis 1982). Although freshly-moulted penguins have no old feathers to reduce their swimming efficiency, their maximum speed of only $10 \mathrm{~km} \mathrm{~h}^{-1}$ is probably the result of their wasted musculature. Post-moult Jackass Penguins can still theoretically outswim anchovies. After feeding, post-moult Jackass Penguins are capable of speeds up to $18.8 \mathrm{~km} \mathrm{~h}^{-1}$ (Fig. 2). This is substantially faster than the average breeding adult and demonstrates the value of fresh plumage, which is smoother than the pre-moult plumage.

\section{Foraging habits}

Although the theoretical foraging ranges of penguins are often large, up to $100 \mathrm{~km}$ for Gentoo Penguins Pygoscelis papua, Adelie Penguins $P$. adelie, Chinstrap Penguins $P$. antarctica (Lishman in press), Rockhopper Penguins Eudyptes chrysocome and Macaroni Penguins E. chrysolophus (Williams \& Siegfried 1980), and up to $500 \mathrm{~km}$ for King Penguins Aptenodytes patagonicus (Croxall \& Prince 1980), my data, and telemetric studies (Trivelpiece et al. unpubl.), indicate that penguins have much smaller foraging ranges than have been supposed.

The greatest density of Jackass Penguins at sea, at $9 \mathrm{~km}$ from Marcus Island, was within the maximum range of $24.2 \mathrm{~km}$ postulated above. Jackass Penguins can potentially travel $48.4 \mathrm{~km}$ during a foraging trip of $11 \mathrm{~h}$. If $18 \mathrm{~km}$ is used in commuting between the island and the foraging area, there is theoretically a further $30.4 \mathrm{~km}$ available for the distance covered by the penguins when actually foraging. There is a tendency for birds to move along the coast rather than out to sea. This has also been reported by Siegfried et al. (1975) and Cooper (1984). The near-shore distribution of the Jackass Penguin is consistent with the distribution of pelagic shoal fish which are found within the $200 \mathrm{~m}$ contour (Crawford 1981).

Siegfried et al. (1975) found that Jackass Penguin dives are of short duration, similar to those within the bay during the present study. Penguins probably do not forage during short dives of about $22 \mathrm{~s}$. Observations from high vantage points on the islands showed 
that during such dives, penguins were travelling in a straight line within 2 to $3 \mathrm{~m}$ of the surface. The long duration of dives outside the bay probably reflects a much deeper dive during which birds forage. Dives of travelling Gentoo and Chinstrap Penguins are also of short duration compared to their foraging dives (Trivelpiece et al. unpubl.). Penguins can dive deeply (Kooyman et al. 1971, Conroy \& Twelves 1972, Kooyman et al. 1982, Adams \& Brown 1983, Lishman \& Croxall 1983) which increases the volume of sea available to them in proximity to their breeding sites compared with that available to other seabirds.

\section{Ecology of prey species}

Although no published data are available on the depth distribution of the Cape Anchovy, other anchovy species, e.g. Engraulis ringens and E. mordax, generally occur within $30 \mathrm{~m}$ of the surface (Guillen et al. 1969, Jordan 1976, Huppert et al. 1980, Johannesson \& Vilchez 1980) as do Jackass Penguins.

The short range of the Jackass Penguin necessitates a distributionally predictable prey (Frost et al. 1976). This condition is satisfied by a single, large, spatially predictable prey patch or many small prey patches which are encountered relatively frequently.

Anchovy school size is highly variable (Smith 1970). The Cape Anchovy occurs in massive schools of many tons of fish (Fig. 5; Stuttaford 1983) and in small, widely scattered schools (Fig. 6); Shelton \& Hutchings 1981, Stuttaford 1983). If penguins fed on single, large, spatially predictable fish schools the birds would all be expected to travel approximately the same distance during a foraging trip irrespective of how much they ingest. If the fish schools were not spatially predictable

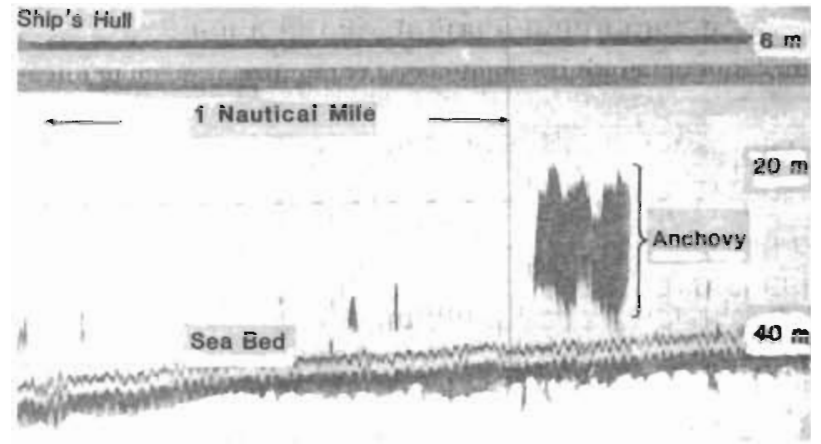

Fig. 5. Echo-trace from a Simrad EK5 echo-sounder set at 38 $\mathrm{kHz}$ with a hull mounted transducer, showing large schools of anchovy. The trace was made approximately $55 \mathrm{~km}$ south of Saldanha Bay $4 \mathrm{~km}$ offshore during mid-May 1983

the birds would be expected to travel very variable distances that bear no relation to the amount of fish ingested. However, for penguins feeding on small schools of randomly distributed prey, where there are numerous prey encounters, a positive correlation between distance travelled and amount of food ingested is expected. The latter is seen in my data (Fig. 3).

Large aggregations of animals have a small surface area/volume ratio compared to small aggregations. When fish school, the mean effective surface area exposed to predators of individual school fish decreases with increasing school size causing the predator-prey encounter rate to decrease (Brock \& Riffenburg 1960, Cushing \& Harding-Jones 1968) but the comparatively small surface area of large schools makes feeding less efficient for planktivores (Eggers 1976). Thus small schools of anchovy may be feeding (Cushing 1977). The incidence of anchovy with full stomachs from small schools compared to large schools

Fig. 6. Echo-trace from a Simrad EK5 echo-sounder, set at $38 \mathrm{kHz}$ with a hull mounted transducer, showing small schools of anchovy (confirmed by mid-water trawl). The trace was made approximately $8 \mathrm{~km} \mathrm{NW}$ of Saldanha Bay during mid-May 1983. The deeper denser schools are lantern fish Lamponyctodes hectoris

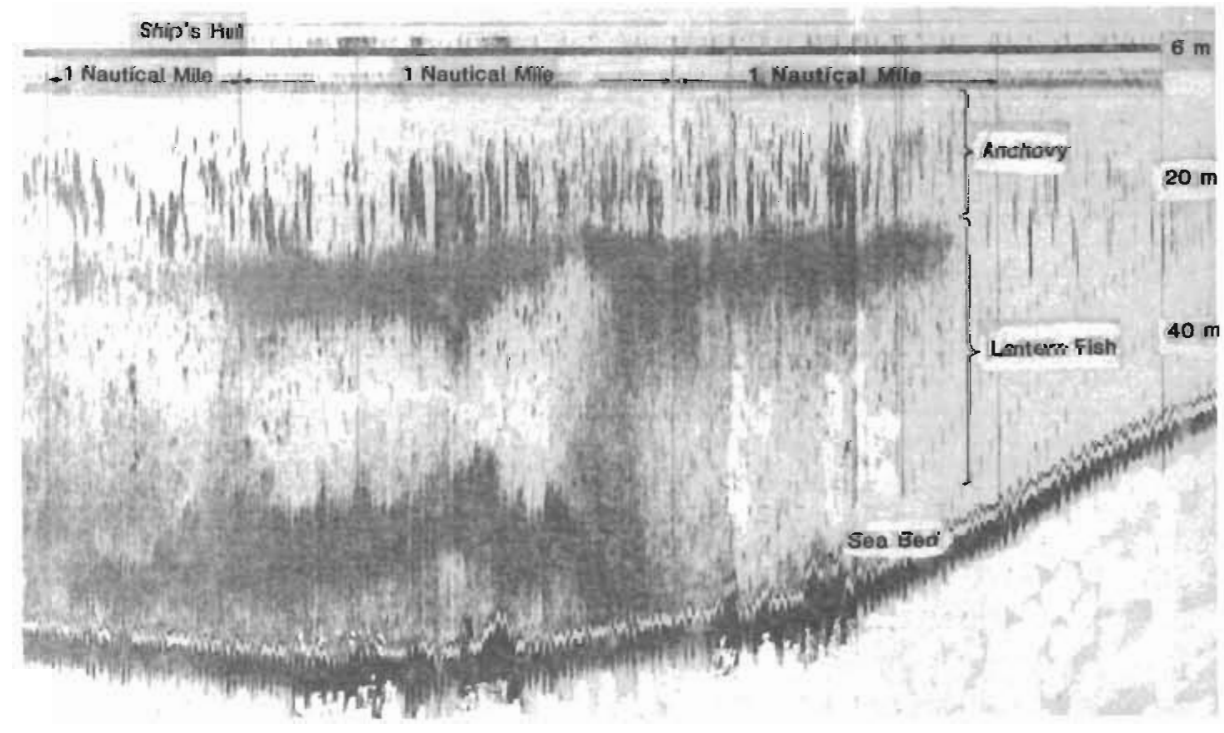


supports this and the even higher incidence of full stomachs of anchovies caught by Jackass Penguins (Table 4) implies that Jackass Penguins are feeding on such small schools. Small schools are likely to be encountered more often under conditions of random search and thus are a spatially predictable food source which can be exploited by the penguin with its limited foraging range.

Acknowledgements. I thank the South African Nature Foundation, the Benguela Ecology Programme of the South African National Committee for Oceanographic Research, the National Geographic Society, and the Frank M. Chapman Memorial fund for financial support. The Sea Fisheries Research Institute gave permission to use their echotraces of anchovy schools and allowed me to undertake research at Marcus Island. Thanks are also due to $\mathrm{C}$. Bain and $\mathrm{J}$. Hanekom of the Nuclear Development Corporation and Gundle Plastics. D. Duffy was invaluable for comments on the manuscript. The research was conducted while I was a recipient of a J. W. Jagger Scholarship of the University of Cape Town.

\section{LITERATURE CITED}

Adams, N. J., Brown, C. R. (1983). Diving depths of the Gentoo Penguin (Pygoscelis papua). Condor 85: 503-504

Barton, D. (1979). Swimming speed of a Little Penguin. Emu 79: 141-142

Boden, B. P., Kampa, E. M. (1967). The influence of natural light on the vertical migrations of an animal community in the sea. Symp. Zool. Soc. Lond. 19: 15-26

Boersma, P. D. (1976). An ecological and behavioral study of the Galapagos Penguin. Living Bird 15: 43-93

Brock, V. E., Riffenburg, R. H. (1960). Fish schooling: a possible factor in reducing predation. J. Cons. Perm. int. Explor. Mer. 25: 307-317

Clark, B. D., Bemis, W. (1979). Kinematics of swimming penguins at Detroit Zoo. J. Zool., Lond. 188: 411-428

Conroy, J. W. H., Twelves, E. L. (1972). Diving depths of the Gentoo Penguin (Pygoscelis papua) and the Blue-eyed Shag (Phalacrocorax atriceps) from the South Orkney Islands. Br. Ant. Surv, Bull. 30: 106-108

Cooper, J. (1978). Moult of the Black-footed Penguin (Spheniscus demersus). Int. Zoo Yearbook 18: 22-27

Cooper, J. (1984). Changes in resource division among four breeding seabirds in the Benguela upwelling system. In: Ledger, J. (ed.) Proc. V Pan-Afr. Orn. Congr. Johannesburg, p. 217-223

Crawford, R. J. M. (1981). Distribution, availability and movements of Anchovy (Engraulis capensis) off South Africa 1964-1976. Fish. Bull. Un. S. Afr. 14: 51-94

Croxall, J. P. (1984). Seabirds. In: Laws, R. M. (ed.) Antarctic ecology. Academic Press, London, p. 533-616

Croxall, J. P., Prince, P. A. (1980). Food, feeding ecology and ecological segregation of seabirds at South Georgia. Biol. J. Linn. Soc. Lond. 14: 103-131.

Cushing, D. H. (1977). Observation on fish schools with the ARL scanner. Rapp. P.-v. Réun. Cons, int. Explor. Mer $170 ; 15-20$

Cushing, D. H., Harding-Jones, F. R. (1968). Why do fish school? Nature, Lond. 218: 918-920

Davies, D. H. (1955). The South African Pilchard (Sardinops ocellata): bird predators, 1953-1954. Investl. Rep. Div Fish. Un. S. Afr. 18: 1-32

Duffy, D. C. (1983). The foraging ecology of Peruvian seabirds. Auk 100: 800-810

Eggers, D. M. (1976). Theoretical effects of schooling by plantivorous fish predators on rate of prey consumption. $\mathrm{J}$ Fish. Res. Bd Can. 33: 196-197

Erasmus, T., Randall, R. M., Randall, B. M. (1981), Oil pollution, insulation and body temperature in the Jackass Penguin, Spheniscus demersus. Comp. Biochem. Physiol. 69 $1-3$

Frost, P. G. H., Siegfried, W. R., Cooper, J. (1976). Conservation of the Jackass Penguin (Spheniscus demersus). Biol. Conserv. 9: 79-99

Furness, R. W., Cooper, J. (1982). Interactions between breeding seabird and pelagic fish populations in the southern Benguela region. Mar. Ecol. Prog. Ser. 8: 243-250

Guillen, O., Calienes, R., de Rondan. R. I. (1969). Contribution al estudio del ambiente de la Anchoveta (Engraulis ringens). Biol. Inst. Mar. Peru 2: 49-76

Hamner, W. H., Hamner, P. P., Strand, S. W., Gilmer, R. W. (1983). Behavior of Antarctic Krill, Euphausia superba: chemoreception, feeding, schooling and moulting. Science 220: 433-435

Hobson, E. S. (1979). Interactions between Piscivorous fishes and their prey. In: Stroud, K. H., Clepper, H. (ed.) Predator-prey systems in fisheries management. Sports fishing Institute, Washington D. C.

Hunter, J. R. (1972). Swimming and feeding behavior of larval anchovy (Engraulis mordax). Fish. Bull. U.S. 70: 821-838

Hunter, J. R., Zweifel, J. R. (1971). Swimming speed, tail beat amplitude and size in Jack Mackerel (Trachurus symmet. ricus) and other fishes. Fish. Bull. U.S. 69: 253-266

Huppert, D. D., MacCall, A. D., Stauffer, G. D., Parker, K. R. McMillan, V. A., Frey, H. W. (1980). California's northern anchovy fishery: biological and economic basis for fishery management. NOAA. Technical Memorandum NMFSSWFC No. 1, p. 1-113

Johanesson, K., Vilchez, R. (1980). Note on hydroacoustic observations of changes in distribution and abundance of some common pelagic fish species in the coastal waters of Peru, with special reference to the anchoveta. International Oceanographic Commission (IOC) Workshop Rep. 28: $287-323$

Jordan, R. (1976). Biologia de la Anchoveta parte 1: Resumen del conocimiento actual. - Reunion de trabajo sobre el fenomeno conocido como 'el Nin̄o'. Guayaquil, Ecuador. F. A. O. Inf. Pesca 185: 359-399

Kooyman, G. L. (1975). Behaviour and physiology of diving. In: Stonehouse, B. (ed.) The biology of penguins. Macmillan Press, London, p. 115-138

Kooyman, G. L., Croxall, J. P., Costa, D. P. (1982). Diving depths and energy requirements of King Penguins. Science 217: 726-727

Kooyman, G. L., Drabek, C. M., Elsner, R., Cambell, W. B. (1971). Diving behavior of the Emperor Penguin (Aptenodytes forsteri). Auk 88: 775-795

Lishman, G. S. (in press). The food and feeding ecology of Adelie and Chinstrap Penguins at Signey Island, South Orkney Islands. J. Zool., Lond.

Lishman, G. S., Croxall, J. P. (1983). Diving depths of the Chinstrap Penguin (Pygoscelis antartica). Br. Ant. Surv. Bull. 61: 21-25

Meinertzhagen, R. (1955). The speed and altitude of bird flight. Ibis $97: 81-117$

Murphy, R. C. (1936). Oceanic birds of South America. Holgate, M. W. (ed.) Macmillan, New York 
Nachtigall, W., Bilo, D. (1980). Strömungsanpassung der Pinguine beim Schwimmen unter Wasser. J. comp. Physiol. 137: $17-26$

Partridge, B. L. (1980). The effect of school size on the structure and dynamics of minnow schools. Anim. Behav. 28: $66-77$

Pitcher, T. J., Partridge, B. L. (1979). Fish school density and volume. Mar Biol. 54: 383-394

Rand, R. W. (1960). The distribution, abundance and feeding habits of the Cape Penguin (Spheniscus demersus) off the South western coast of the Cape Province. Investl. Rep Div. Fish. Un. S. Afr. 41: 1-28

Scholander, P. F. (1940). Experimental investigations of the respiratory function of diving mammals and birds. Hvalråd. Skr. 22: 1-131

Schreiweis, D. O. (1982). A comparative study of the appendicular musculature of penguins (Aves: Sphenisciformes). Smithson. contr. Zool. 341

Shelton, P. A., Hutchings, L. (1981). A note on diurnal spawning rhythm in the anchovy, Engraulis capensis. Fish. Bull. Un. S. Afr. 14: 47-50

Siegel, S. (1956). Nonparametric statistics. McGraw-Hill Book Co., New York

Siegfried, W. R., Frost, P. G. H., Kinahan, J. B., Cooper, J. (1975). Social behaviour of Jackass Penguins at sea. Zool Afr. 10: $87-100$

Smith, P. E. (1970). The horizontal dimensions and abundance of fish schools in the upper mixed layer as measured by sonar. Proc. Symp. on Biol. Sound Scattering in the Ocean, Warrington, Virginia, p. 563-600

South African Journal of Science. (1979). Rehabilitated Jackass penguins return to St Croix Island. S. Afr. J. Sci. 75: 524
Stuttaford, M. (1983). Anchovy shoaling as seen by fishermen S. A. Ship. News and Industr Rev. Feb: 18-23

Talbot, M. S. (1974). Distribution of Euphausiid crustaceans from the Agulhas current. Zool. Afr. 9: 93-145

Thiriot, A. (1978). Zooplankton communities in the West African upwelling area. In: Boje, R., Tomczak, T. (ed.) Upwelling ecosystems. Kiel symp. Sept. 1975. Springer, Berlin, p. $32-61$

Wardle, C. S. (1975). Limit of fish swimming speed. Nature, Lond. 255: 725-727

Webb, P. (1975). Hydrodynamics and energetics of fish propulsion. Bull. Fish. Res. Bd Can. 190: 1-159

Williams, A. J., Siegfried, W. R. (1980). Foraging ranges of Krill eating penguins. Polar Rec. 20: 159-162

Wilson, E. A. (1907). Vertebrata, Section II, Aves. In: National Antarctic Expedition 1901-1904. Natural history, Zoology. British Museum, London, p. 1-121

Wilson, R. P. (1985). Seasonality in diet and breeding success of the Jackass Penguin, Spheniscus demersus. J. Orn. (Berl.) 126: 53-62

Wilson, R. P. (1985). Diurnal foraging behaviour of the Jackass Penguin, Spheniscus demersus. Ostrich 56: 212-214

Wilson, R. P., Bain, C. A. R. (1984a). An inexpensive speed meter for penguins at sea. J. Wildl. Mgmt 48: 1360-1364

Wilson, R. P., Bain, C. A. R. (1984b). An inexpensive depth gauge for penguins. J. Wildl. Mgmt 48: 1077-1084

Zusi, R. L. (1975). An interpretation of skull structure in penguins. In: Stonehouse, B. (ed.) The biology of penguins. Macmillan Press, London, p. 59-84 